\title{
ICI transfers most of its research to new Zeneca biosciences company
}

London. The British chemicals giant Imperial Chemical Industries (ICI) is to split its research activity in two following the separation of its bulk chemicals and bioscience activities into separate companies. Two-thirds of its total research budget, which last year was $£ 720$ million (US\$1 billion - - the highest of any company in Britain - will now be transferred to a new company, Zeneca Group, being set up to bring together ICI's interests in pharmaceuticals, agrochemicals and seeds. The name, which comes from the word "zenith", was changed from the originally proposed title ICI Bioscience.

The planned demerger, first proposed last summer and still awaiting formal endorsement by shareholders after last week's approval by the board of directors, represents one of the biggest changes in the company's history. ICI was formed in 1926 as a conglomerate of smaller chemical companies trying to achieve economies of scale in both research and production that were needed to compete internationally, in particular against Germany's IG Farben.

The reversal of that trend reflects a recognition of the different intensity of research and development in the two sectors. "The name of the game has to be focus", Sir Denys Henderson, ICI's chairman, said last week.

The division of research activities follows this logic. In the past, ICI built up large centralized research laboratories, based primarily at Runcorn in Cheshire, to do research that it hoped would eventually lead to new products or processes. Since the mid1980 s, however, research has been increasingly decentralized, and research teams linked directly to individual product lines.

The creation of Zeneca continues that pattern, with virtually no overlapping research between the two new companies. "The idea was to create a clear-cut separation in both research and technology", says Peter Doyle, formerly director of research and technology of ICI who will become executive director of Zeneca responsible for research, technology and manufacturing.

Exceptions will involve the services provided by the Central Toxicology Laboratory at Macclesfield and the Group Environmental Laboratory (to be known as the Brixham Environmental Laboratory). Both will become part of Zeneca, but will sign contracts with ICI to provide specialist services as a 'special customer'. Research and development in areas ranging from specialized plastics to chlorofluorocarbon substitutes will remain an important activity for

the "new ICI", which will have a research budget of about $£ 250$ million a year and a work force of 5,000.

The split recognizes the fact that the ICI'S bioscience activities, which grew rapidly in the 1980 s, are now large enough to survive on their own. Zeneca itself will

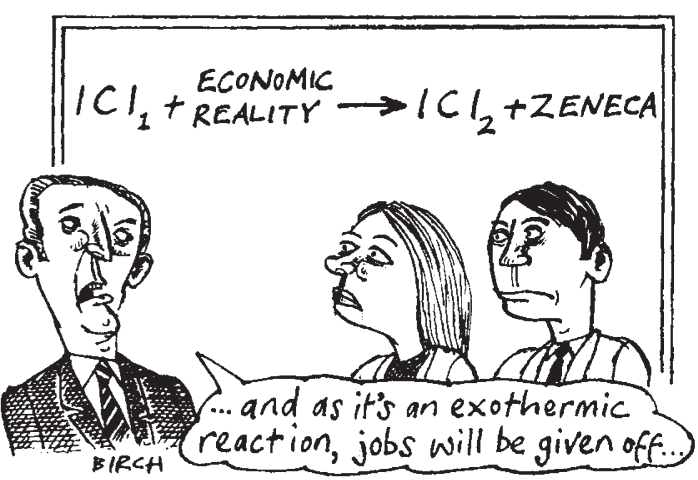

initially have sales of approximately $£ 4$ billion a year, and aims to be "a major force in the bioscience industry", according to its chief executive David Barnes.

The demerger will permit the growth of technologies based on new fields of science - in particular genetics and molecular biology - that some feel were neglected in the past in favour of the more traditional disci-

\section{Kessler stays, Healy goes}

Washington. David Kessler has been asked to stay on as commissioner of the US Food and Drug Administration (FDA); on the same day (26 February), the Clinton administration accepted the resignation of Bernadine Healy as director of the US National Institutes of Health (NIH).

Kessler directs an agency with responsibility for the safety of foods (except meat and poultry) and cosmetics and the safety and efficacy of human and animal drugs and medical devices. Since taking up the post in late 1990 , his biggest challenge has been to restore the reputation of an agency damaged by the discovery that several FDA officials had accepted money to speed up the review of certain generic drugs.

Kessler has cracked down on companies making unfounded commercial and health claims on food labels and has also tried to reduce the time needed to review therapies for patients with AIDS and other life-threatening diseases. He has also worked closely with Congress and the drug industry to plines related to bulk chemical production. The impact of these new techniques, each based on what the company describes as a "common science base" underlying all Zeneca's activities, is expanding rapidly. For example, the development of new seed strains has been significantly enhanced by the introduction of genetic fingerprinting, which allows research workers to evaluate the effects of breeding techniques without a lengthy wait for genes to express themselves.

In order to encourage a more longterm focus, a "strategic research and development fund" of several million pounds has been set up to support grant applications from company scientists. However, any application for money from this fund still has to demonstrate how the research is expected to contribute directly to a specific product area.

Many ICI scientists regret the disappearance of the central laboratories.

"For young scientists, joining ICI now means that they do not have the freedom that they would have had in the corporate laboratory", says a former ICI chemist.

Doyle, however, believes that a demand for greater accountability of research reflects the times. "These days, exploitation and innovation are key themes, and we want to tie research more tightly to strategic work", he says.

David Dickson

create a system of user fees that will pay for an additional 600 medical reviewers.

In contrast, Healy's two years at $\mathrm{NIH}$ have been marked by continuing tension between the agency and Congress as well as widespread unhappiness in the research community with her effort to draw up a strategic plan. Although she has won credit for rapidly expanding research on the health of women and minorities, she has been criticized for going along with the Bush administration's ban on fetal tissue transplantation research and its opposition to legislative changes to strengthen various initiatives.

Healy will leave on 30 June and will return to the Cleveland (Ohio) Clinic Foundation, from which she has been on leave. Her resignation, together with Walter Massey's departure from the National Science Foundation at the end of the month, gives the new president a chance to put his stamp on the agencies that fund most of the country's academic research.

Diane Gershon \& Jeffrey Mervis 